\title{
ANALISIS PENERAPAN SISTEM INFORMASI AKUNTANSI DAN KUALITAS LAPORAN KEUANGAN UMKM DALAM MENGEMBANGKAN BISNIS DI KOTA BATAM
}

\author{
Syahril Effendi ${ }^{1)}$, Baru Harahap ${ }^{2)}$ \\ Dosen Universitas Putera Batam \\ email: syahril@puterabatam.ac.id
}

\begin{abstract}
This research is motivated by the number of companies in Batam that closed and left Batam which caused many unemployment, so the role of MSMEs in Batam is now very much needed. The focus of this study is to determine the application of accounting information systems and the quality of MSME financial reports on business development in Batam City. This research was conducted at Micro, Small and Medium Enterprises (SMEs) in Batam City, Riau Islands Province. The subjects of this study are business people or MSME businesses that utilize revolving funds from the City Government (Pemko) of Batam, which are recorded at the Batam City Cooperative and MSME Office. The population in this study are business or MSME businesses that utilize revolving funds from the City Government (Pemko) of Batam as many as 2,105 businesses and by using the Slovin formula so that the sample becomes 96 MSMEs. All samples come from SMEs who run businesses in Batam City. Research shows that the application of accounting information systems has a significant effect on business development in Batam City, the quality of MSME financial reports has a significant effect on business development in Batam City, the application of accounting information systems and the quality of MSME financial reports simultaneously has a significant effect on business development in Batam City.
\end{abstract}

Keywords: accounting information systems; quality of financial statements; MSME; business development

\section{PENDAHULUAN}

Perkembangan Teknologi informasi saat ini sangat berkembang pesat, apalagi telah terbentuknya kawasan ekonomi terintegrasi di wilayah Asia Tenggara atau yang disebut dengan Masyarakat Ekonomi ASEAN (MEA) pada tahun 2015. perkembangan teknologi informasi dan komunikasi saat ini telah membawa pengaruh positif bagi masyarakat terutama pelaku usaha yang menjalankan aktivitas bisnisnya dalam berbagai bidang. Penggunaan teknologi yang dimaksud adalah komputer yang dapat mengolah data bisnis dari kegiatan operasional usaha, baik kegiatan penjualan, pembelian, pengajian, produksi dan keuangan. Laporan keuangan berkaitan erat dengan sistem informasi akuntansi karena kegiatan ini pada dasarnya merupakan kegiatan mengolah data mulai dari pencatatan transaksi keuangan sampai dengan penyajian laporan keuangan yang digunakan untuk menganalisa data keuangan dari perusahaan (Hastuti, 2012).

Sejak 2001 hingga 2017 dana bergulir yang sudah disalurkan kepada pelaku UMKM mencapai Rp 77,432 miliar dengan bunga 6 persen per tahun. Dana bergulir tersebut merupakan bentuk komitmen Pemerintah Kota (Pemko) Batam dalam mendukung pelaku UMKM dengan penyaluran bantuan modal. Pemko Kota Batam memberikan Jangka waktu pengembalian maksimal 3 tahun yang disesuaikan dengan kemampuan peminjam, tetapi dana bergulir tersebut hanya dimanfaatkan 2.105 dari 75 ribuan UMKM (Aquinus, 2018). Dana yang sudah dimanfaatkan tentunya UMKM memiliki kewajiban dalam memahami akuntansi untuk menyajikan laporan keuangan sebagai pertanggungjawaban usaha yang sedang dijalankan.

Permasalahan di atas, menuntut UMKM untuk memiliki pengetahuan akuntansi dalam mengelola bisnisnya yang juga dapat dilihat pada kualitas laporan keuangan yang disajikan dari kegiatan operasional kegiatan yang dijalankannya. Begitu juga penggunaan sistem 
informasi akuntansi dapat memberikan kemudahan kepada UMKM dalam menyelesaikan laporan keuangan, sehingga kualitas laporan dapat dijaga dengan baik.

Pemanfaatan Teknologi Informasi dalam kegiatan sehari hari sangatlah penting, Hal ini berguna dalam menunjang kehidupan yang jauh lebih baik. Dengan adanya Teknologi Informasi jadi sangatlah membantu kegiatan jadi lebih efektif dan efisien. Teknologi informasi adalah teknologi informasi adalah suatu teknologi yang digunakan untuk mengolah data, termasuk memproses, mendapatkan, menyusun, menyimpan, memanipulasi data dalam berbagai cara untuk menghasilkan informasi yang berkualitas, yaitu informasi yang relevan, akurat dan tepat waktu, yang digunakan keperluan pribadi, bisnis, dan pemerintahan dan merupakan informasi yang strategis untuk pengambilan keputusan (Sutabri, 2014).

Berdasarkan penjabaran diatas maka rumusan masalah adalah Seberapa besar Pengaruh Penerapan Sistem Informasi Akuntansi Dan Kualitas Laporan Keuangan UMKM Terhadap Pengembangan Bisnis di Kota Batam baik secara pasrsial maupun secara simultan. Tujuan penelitian adalah Untuk mengetahui Pengaruh Penerapan Sistem Informasi Akuntansi Dan Kualitas Laporan Keuangan UMKM Terhadap Pengembangan Bisnis di Kota Batam. baik secara pasrsial maupun secara simultan.

\section{TINJAUAN PUSTAKA}

\section{Penerapan Sistem Informasi Akuntansi}

Menurut (Mulyadi, 2016), sistem akuntansi adalah organisasi, formulir, catatan dan laporan yang dikoordinasi sedemikian rupa untuk menyediakan informasi keuangan yang dibutuhkan oleh manajemen guna memudahkan pengelolaan perusahaan. Sistem informasi akuntansi adalah sebuah sistem yang memproses data dan transaksi guna menghasilkan inforamsi yang bermanfaat untuk merencanakan, mengendalikan dan mengoperasikan bisnis (Krismiaji, 2010).

Berdasarkan penjelasan di atas, maka dapat disimpulkan bahwa sistem informasi akuntansi merupakan sistem yang digunakan dalam memproses data dan transaksi bisnis yang dapat dijadikan sebuah informasi keuangan bagi pihak pelaku bisnis dalam mengambil keputusan. Hal ini tentunya memberikan manfaat dalam kegiatan operasional perusahaan untuk kelangsungan hidup usahannya di masa yang akan datang.

Sistem informasi akuntansi sangat dibutuhkan oleh pelaku usaha, dimana pelaku usaha yang dimaksud adalah Usaha Mikro Kecil dan Menengah (UMKM) dalam menjalankan bisnisnya agar selalu dapat bersaing dan berkembang. Pelaku UMKM membutuhkan kompetensi sumber daya manusia yang memiliki pengetahuan terhadap pekerjaan yang akan dilakukan, terutama dalam menyajikan laporan keungan yang berkualitas sesuai Standar Akuntansi Keuangan Entitas Mikro Kecil Menenggah (SAK-EMKM). Standar ini disusun untuk memenuhi kebutuhan pelaporan keuangan entitas mikro, kecil, dan menengah, yang diberlakukan pada 1 januari 2018 sehingga UMKM dapat menyajikan laporan keuangan yang bekualitas. Penelitian sebelumnya menjelaskan ada pengaruh antara kompetensi sumber daya manusia (SDM) terhadap kualitas laporan keuangan Pada SKPD Kabupaten Jember (Humairoh, 2013).

\section{Kualitas Laporan Keuangan UMKM}

Kualitas informasi laporan keuangan memberikan kemudahan bagi pemakai, sehingga memiliki pengetahuan yang memadai tentang aktivitas ekonomi dan bisnis, akuntansi, serta kemauan untuk mempelajari informasi dengan ketekunan yang wajar. namun demikian, informasi kompleks yang seharusnya dimasukkan dalam laporan keuangan tidak dapat dikeluarkan hanya atas dasar pertimbangan bahwa informasi tersebut sulit untuk dapat dipahami oleh pemakai tertentu (Roviyantie, 2011).

Kualitas informasi akuntansi yang disajikan dalam bentuk laporan keuangan dapat digunakan dalam pengambilan keputusan. Bagian akuntansi dituntut untuk dapat menghasilkan informasi yang relevan, akurat dan tepat waktu. Apabila semua faktor telah dipertimbangkan maka manajemen mempunyai risiko yang lebih kecil dalam membuat kesalahan di dalam 
pengambilan keputusan.

Standar Akuntansi Pemerintahan, laporan keuangan pemerintah dapat dikatakan berkualitas apabila laporan tersebut (1) andal, (2) relevan, (3) dapat dipahami, dan (4) dapat dibandingkan. Laporan keuangan yang berkualitas menunjukkan bahwa pihak manajemen bertanggung jawab sesuai dengan wewenang yang dilimpahkan kepadanya dalam pelaksanaan tanggung jawab mengelola organisasi. Kualitas merupakan suatu penilaian terhadap output pusat pertanggungjawaban atas suatu hal, baik itu dilihat dari segi yang berwujud seperti barang maupun segi yang tidak berwujud, seperti suatu kegiatan. (Peraturan Pemerintah Nomor 71, 2010).

Achim dan Chis (2014) menjelaskan bahwa kandungan kualitas kegunaan keputusan informasi akuntansi meliputi komponen-komponen kandungan dari nilai relevan, yaitu ketepatwaktuan (timeliness), nilai umpan balik (feedback value), dan nilai prediktif (predictive value), dan komponen-komponen kandungan reliabilitas, yaitu penggambaran yang senyatanya (representational faithfulness), netralitas (neutrality), dan dapat diperiksa (verifiability). Selain itu juga terdapat kualitas sekunder, sebagai penghubung antara kualitas primer, yaitu komparabilitas (comparability) dan taat asas (consistency).

Kualitas pelaporan keuangan dapat diukur dengan beberapa indikator, yaitu: 1) Manfaat dari laporan keuangan yang dihasilkan, 2) Ketepatan waktu pelaporan keuangan, 3) Kelengkapan informasi yang disajikan, 4) Penyajian secara jujur, 5) Isi laporan keuangan dapat diverifikasi, 6) Isi laporan keuangan dapat dibandingkan, 7) Keakuratan dan kejelasan informasi yang disajikan. Hal ini sesuai dengan unsur-unsur yang terkandung dalam empat prasyarat normatif kualitatif laporan keuangan, yaitu: relevan, andal, dapat dibandingkan, dan dapat dipahami (Peraturan Pemerintah Republik Indonesia Nomor 7, 2010).

Penjelasan di atas dapat disimpulkan bahwa kualitas laporan keuangan dapat menghasilkan informasi yang relevan, akurat dan tepat waktu, dipahami, dan dapat dibandingkan. Informasi ini memiliki manfaat yang sangat penting bagi pihak manajemen sebagai dasar dalam mengambil keputusan.

\section{Pengembangan Bisnis}

Pelaku UMKM di Kota Batam saat ini sangat berkembang pesat, dimana Kamar Dangang Indonesia (KADIN) mengadakan deklarasi yang pertama yang bertujuan mengingatkan Pemerintah Kota Batam bahwa perekonomian yang kuat dan dapat bertahan adalah ditandai dengan tumbuh kembangnya UMKM. Kegiatan ini dilaksanakan sebagai wujud kepedulian terhadap perekonomian Batam yang saat ini menurun drastis. Sebab banyak perusahaan yang tutup dan hengkang dari Batam yang mengakibatkan banyaknya pengangguran. Di tengah perekonomian Kota Batam yang saat ini anjlok pemerintah harus menumbuh-kembangkan UMKM (Rahmadani, 2017).

\section{Kerangka Pemikiran}

(Sugiyono, 2013: 60) mengemukakan bahwa seorang peneliti harus menguasai teori-teori ilmiah sebagai dasar menyusun kerangka pemikiran yang membuahkan hasil hipotesis. Sedangkan Kerangka pemikiran ialah penjelasan sementara terhadap gejala yang menjadi objek permasalah.

Maka dari itu dapat dijelaskan bahwa objek permasalahan yang di angkat dalam penelitian ini ialah "Analisis Penerapan Sistem Informasi Akuntansi Dan Kualitas Laporan Keuangan UMKM Terhadap Pengembangan Bisnis di Kota Batam”. Konsep yang telah dijelaskan tersebut dapat digambarkan seperti di bawah ini: 


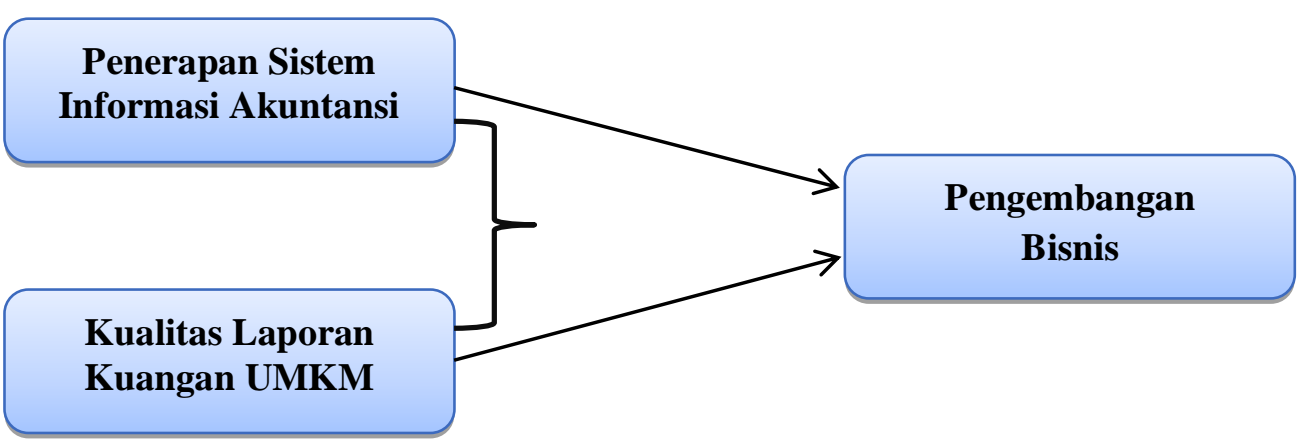

Gambar 1. Kerangka Pemikiran hipotesis:

Berdasarkan kerangka pemikiran dalam penelitian ini, maka penulis mengajukan

$\mathrm{H}_{1}$ : Penerapan Sistem Informasi Akuntansi berpengaruh signifikan terhadap Pengembangan Bisnis di Kota Batam.

$\mathrm{H}_{2}$ : Kualitas Laporan Keuangan UMKM berpengaruh signifikan terhadap Pengembangan Bisnis di Kota Batam.

$\mathrm{H}_{3}$ : Penerapan Sistem Informasi Akuntansi dan Kualitas Laporan Keuangan UMKM berpengaruh signifikan terhadap Pengembangan Bisnis di Kota Batam.

\section{METODE}

Penelitian adalah suatu proses mencari sesuatu secara sistematik dalam waktu yang lama dengan menggunakan metode ilmiah serta aturan-aturan yang berlaku. Untuk dapat menghasilkan suatu penelitian yang baik, maka peneliti bukan hanya mengetahui aturan permainan, tetapi juga harus mempunyai keterampilan-keterampilan dalam melaksanakan penelitian. Untuk menerapkan metode ilmiah dalam praktek penelitian, maka diperlukan suatu desain penelitian, yang sesuai dengan kondisi, seimbang dengan penelitian yang dikerjakan(Nazir, 2014: 70).

Penelitian ini merupakan penelitian kausalitas dengan variabel independen yaitu Penerapan Sistem Informasi Akuntansi $\left(\mathrm{X}_{1}\right)$ dan Kualitas Laporan Keuangan UMKM $\left(\mathrm{X}_{2}\right)$, kemudian variabel dependen dalam penelitian ini yaitu Pengembangan Bisnis (Y). Penelitian ini dilaksanakan pada Usaha Mikro Kecil Menengah (UMKM) di Kota Batam Propinsi Kepulauan Riau. Subjek penelitian ini adalah para pelaku bisnis atau usaha UMKM yang memanfaatkan dana bergulir dari Pemerintah Kota (Pemko) Batam, dimana tercatat pada Dinas Koperasi dan UMKM Kota Batam. Populasi dalam penelitian ini adalah pelaku bisnis atau usaha UMKM yang memanfaatkan dana bergulir dari Pemerintah Kota (Pemko) Batam adalah sebanyak 2.105 usaha. Teknik pengambilan sampel dari populasi tersebut menggunakan rumus Slovin menghasilkan sampel 96 pelaku UMKM dalam menjalankan bisnis di Kota Batam. Data yang diambil dalam penelitian ini menggunakan data primer dengan membagikan kuesioner kepada jumlah responden yang menjadi sampel dalam penelitian ini. Metode analisis yang digunakan adalah persamaan Regersi Linear Berganda $Y=\mathbf{a}+\mathbf{b}_{1} \mathbf{X}_{1}+\mathbf{b}_{2} \mathbf{X}_{2}+\varepsilon$.

Keterangan:

$\begin{array}{ll}\mathrm{Y} & =\text { Pengembangan Bisnis di } \\ \mathrm{A} & =\text { Konstanta persamaan regresi } \\ \mathrm{b}_{1}, \mathrm{~b}_{2} & =\text { Koefisien regresi } \\ \mathrm{X}_{1} & =\text { Penerapan Sistem Informasi Akuntansi } \\ \mathrm{X}_{2} & =\text { Kualitas Laporan Keuangan UMKM } \\ \mathrm{e} & =\text { Error/ epsilon (faktor lain yang mempengaruhi) }\end{array}$




\section{HASIL DAN PEMBAHASAN}

\section{A. Hasil Uji Asumsi Klasik}

1). Hasil Uji Multikolinieritas

Hasil pengujian multikolinieritas dapat dilihat pada tabel berikut:

Tabel 1. Hasil Uji Multikolinieritas

\begin{tabular}{|c|r|r|c|}
\hline \multirow{2}{*}{ Variabel } & \multicolumn{2}{|c|}{ Collinearity Statistics } & \multirow{2}{*}{ Kesimpulan } \\
\cline { 2 - 3 } & Tolerance & VIF & \\
\hline$X_{1}$ & $\mathbf{0 . 4 6 3}$ & $\mathbf{2 , 1 5 9}$ & Tidak Terjadi Multikolinieritas \\
$\mathrm{X}_{2}$ & $\mathbf{0 . 4 6 3}$ & $\mathbf{2 , 1 5 9}$ & Tidak Terjadi Multikolinieritas \\
\hline
\end{tabular}

Berdasarkan hasil pengujian multikolinearitas semua variabel diatas memiliki nilai VIF dibawah angka 10 dan nilai tolerance lebih dari 0.1 . Hal ini menunjukkan tidak terjadi multikolinieritas atau hubungan antar variabel independen dalam model regresi tersebut.

\section{2). Hasil Uji Normalitas} berikut:

Hasil pengujian asumsi normalitas dalam penelitian ini dapat dilihat pada gambar sebagai

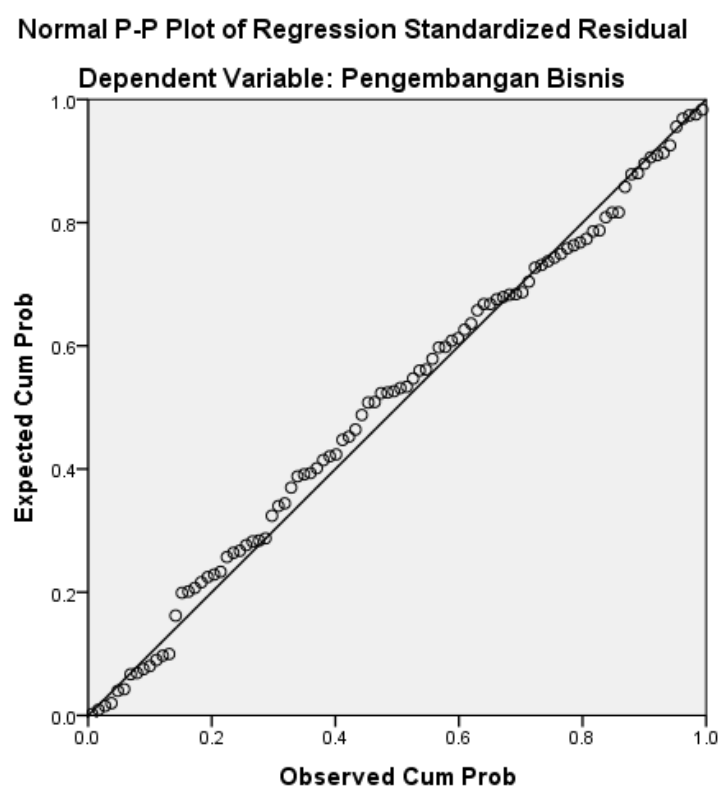

Gambar 2. Hasil Uji Normalitas

Dari hasil pengujian normalitas di atas, menunjukkan titik-titik menyebar di sekitar garis diagonal untuk variabel dependen Pengembangan Bisnis di . Penyebaran tersebut mengikuti arah garis diagonal. Hal ini menunjukkan bahwa data tersebar dengan normal dan model regresi tersebut layak untuk dipakai. 


\section{3). Hasil Uji Heteroskedastisitas}

Hasil pengujian heteroskedastisitas dapat dilihat pada gambar sebagai berikut:

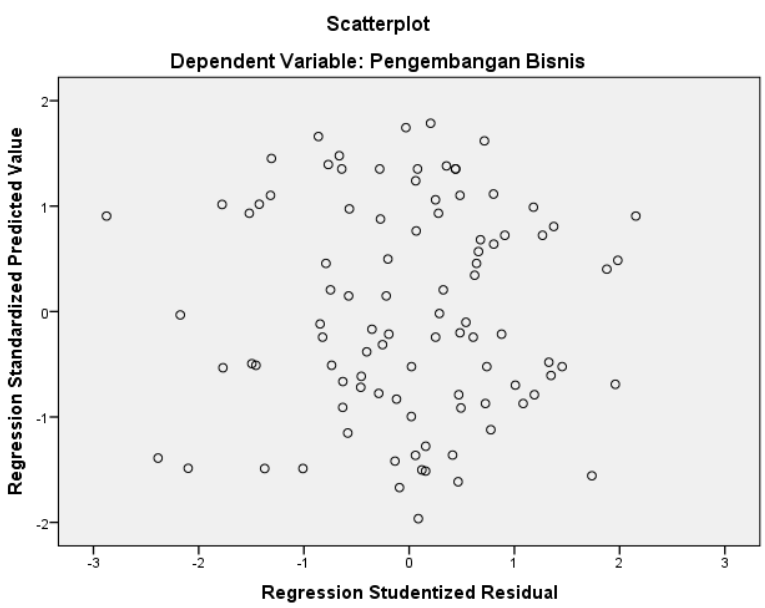

Gambar 3 Hasil Uji Heteroskedastisitas

Dari gambar di atas, dapat dilihat bahwa titik-titik menyebar di atas dan dibawah angka nol pada sumbu $\mathrm{Y}$ dan tidak membentuk pola yang jelas sehingga tidak terjadi masalah heteroskedastisitas.

\section{B. Hasil Uji Hipotesis}

1). Analisis Regresi Berganda (Multiple Regression Linear)

Untuk uji hipotesis ini digunakan analisis regresi berganda (Multiple Regression Linear).

Tabel 2. Hasil Uji Regrsi Linier Berganda

\begin{tabular}{|c|c|c|c|}
\hline \multicolumn{4}{|c|}{ Dependent Variable: Pengembangan Bisnis di (Y) } \\
\hline Variabel & $\begin{array}{c}\text { Unstandardized Coefficient } \\
\text { B }\end{array}$ & $\mathbf{t}$ & Sig. \\
\hline$\overline{\text { (Cons }}$ & 2.549 & $\mathbf{1 . 4 3 9}$ & 0.000 \\
\hline Penerapan Sistem Informasi Akuntansi $\left(\mathrm{X}_{1}\right)$ & 0.353 & 9.396 & 0.000 \\
\hline Kualitas Laporan Keuangan UMKM $\left(\mathrm{X}_{2}\right)$ & 0.948 & 11.953 & 0.000 \\
\hline
\end{tabular}

Persamaan regresi dan hasil pengujian hipotesis adalah sebagai berikut:

$$
\mathrm{Y}=\mathbf{2 . 5 4 9}+0.353 \mathrm{X}_{1}+0.948 \mathrm{X}_{2}+e
$$

Dari persamaan diatas dapat disimpulkan bahwa setiap 1 skor Penerapan Sistem Informasi Akuntansi $\left(\mathrm{X}_{1}\right)$ bertambah dengan satu-satuan maka akan mempengaruhi Y_Pengembangan Bisnis di sebesar 0.353 (35.30\%), dan setiap 1 skor Kualitas Laporan Keuangan UMKM $\left(\mathrm{X}_{2}\right)$ bertambah maka akan mempengaruhi Y_Pengembangan Bisnis di sebesar $0.948(94.80 \%)$ selebihnya di pengaruhui oleh faktor lain.

\section{2). Hasil Uji t}

Hasil uji t dapat dilihat pada tabel berikut:

Tabel 3. Hasil Uji t

\begin{tabular}{lcccl}
\hline \multicolumn{5}{c}{ Dependent Variable: Pengembangan Bisnis di (Y) } \\
\hline \multicolumn{1}{c}{ Variabel } & $\begin{array}{c}\text { Unstandardized } \\
\text { Coefficient }\end{array}$ & & & Kesimpulan \\
& $\mathbf{B}$ & $\mathbf{T}$ & Sig. & \\
\hline (Constant) & $\mathbf{2 . 5 4 9}$ & $\mathbf{1 . 4 3 9}$ & $\mathbf{0 . 0 0 0}$ & Signifikan \\
Penerapan Sistem Informasi & $\mathbf{0 . 3 5 3}$ & $\mathbf{9 . 3 9 6}$ & $\mathbf{0 . 0 0 0}$ & Signifikan \\
Akuntansi $\left(\mathrm{X}_{1}\right)$ & & & & \\
Kualitas Laporan Keuangan & $\mathbf{0 . 9 4 8}$ & $\mathbf{1 1 . 9 5 3}$ & $\mathbf{0 . 0 0 0}$ & Signifikan \\
UMKM $\left(\mathrm{X}_{2}\right)$ & & & & \\
\hline
\end{tabular}




\section{a. Hasil Pengujian Penerapan Sistem Informasi Akuntansi $\left(X_{1}\right)$ Terhadap Pengembangan} Bisnis di Kota Batam (Y)

Hasil dari terhadap variabel dependen Pengembangan Bisnis di yang diukur dengan Y_Pengembangan Bisnis di sebesar 0.000 dan nilai koefisien sebesar $\mathbf{0 . 3 5 3}$ (83.2\%). Nilai probabilitas yang kurang dari 0.05 menunjukkan bahwa Penerapan Sistem Informasi Akuntansi berpengaruh signifik Tabel 3 di atas menunjukkan bahwa nilai probalitas Penerapan Sistem Informasi Akuntansi terhadap Pengembangan Bisnis di Kota Batam. Nilai koefisien 0.353 (26.2\%) menunjukkan arah pengaruh positif dari Penerapan Sistem Informasi Akuntansi.

\section{b. Hasil Pengujian Kualitas Laporan Keuangan UMKM $\left(\mathbf{X}_{2}\right)$ Terhadap Pengembangan Bisnis di Kota Batam (Y)}

Hasil dari Tabel 3 di atas menunjukkan bahwa nilai probalitas Kualitas Laporan Keuangan UMKM terhadap variabel dependen Pengembangan Bisnis di yang diukur dengan Y_Pengembangan Bisnis di sebesar 0.000 dan nilai koefisien sebesar 0.948 (30.9\%). Nilai probabilitas yang kurang dari 0.05 menunjukkan bahwa Kualitas Laporan Keuangan UMKM berpengaruh signifikan terhadap Pengembangan Bisnis di Kota Batam. Nilai koefisien 0.948 $\mathbf{5 7 . 8 \%}$ ) menunjukkan arah pengaruh positif dari Kualitas Laporan Keuangan UMKM.

\section{3). Hasil Uji F}

Hasil pengujian $\mathrm{F}$ dapat dilihat pada tabel berikut:

Tabel 4. Hasil Uji F

\begin{tabular}{cccc}
\hline Variabel Dependen & F & Sig. & Kesimpulan \\
\hline Y_Pengembangan Bisnis di & $\mathbf{4 2 7 , 2 6 9}$ & $\mathbf{0 . 0 0 0}$ & Signifikan \\
\hline
\end{tabular}

c. Hasil Pengujian Variabel Penerapan Sistem Informasi Akuntansi $\left(X_{1}\right)$ dan Kualitas Laporan Keuangan UMKM $\left(X_{2}\right)$ secara simultan Terhadap Pengembangan Bisnis di Kota Batam (Y)

Berdasarkan hasil uji F, nilai F yang diperoleh untuk variabel dependen Pengembangan Bisnis di sebesar 427,269 dengan nilai probabilitasnya 0.000 . Karena nilai signifikansi kurang dari 0.05 maka dapat disimpulkan bahwa model regresi tersebut dapat digunakan untuk memprediksi Pengembangan Bisnis di Kota Batam.

\section{4). Hasil Uji Koefisien Determinasi $\left(\mathbf{R}^{2}\right)$}

Tabel 5. Hasil Uji Koefisien Determinasi $\left(\mathrm{R}^{2}\right)$

\begin{tabular}{cccc}
\hline Variabel Dependen & $\boldsymbol{R}$ & $\boldsymbol{R}$ Square & Adjusted $\boldsymbol{R}$ Square \\
\hline $\begin{array}{c}\text { Y_Pengembangan Bisnis } \\
\text { di }\end{array}$ & $\mathbf{9 5 . 0 \%}$ & $\mathbf{9 0 . 2 \%}$ & $\mathbf{9 0 . 0 \%}$ \\
\hline
\end{tabular}

Hasil pengujian menunjukkan bahwa nilai Adjusted $R$ Square $\left(\mathrm{R}^{2}\right)$ untuk model penelitian penulis adalah sebesar $\mathbf{9 0 . 0 \%}$. Nilai Adjusted $R$ Square $\left(\mathrm{R}^{2}\right)$ sebesar $\mathbf{9 0 . 0 \%}$ ini mengindikasikan bahwa variabel independen dapat menjelaskan variabel dependen sebesar $\mathbf{9 0 . 0 \%}$, sedangkan $\mathbf{1 0 . 0 \%}$ lainnya dijelaskan oleh faktor lain yang tidak terdapat dalam model.

\section{SIMPULAN}

Berdasarkan hasil penelitian pada bab-bab sebelumnya, menunjukkan bahwa:

1. Penerapan Sistem Informasi Akuntansi berpengaruh positif dan signifikan terhadap Pengembangan Bisnis di Kota Batam.

2. Kualitas Laporan Keuangan UMKM berpengaruh positif dan signifikan terhadap Pengembangan Bisnis di Kota Batam. 
3. Penerapan Sistem Informasi Akuntansi dan Kualitas Laporan Keuangan UMKM secara bersama-sama memiliki pengaruh yang positif dan signifikan terhadap Pengembangan Bisnis di Kota Batam.

\section{SARAN}

Adapun rekomendasi yang dapat disarankan penulis untuk penelitian selanjutnya adalah:

1. Perlu melakukan pendataan secara rutin terhadap objek pajak reklame yang sudah ada sehingga dapat diketahui potensi yang sebenarnya melalui data objek pajak tersebut. Selain itu proses penetapan target harusnya memperhatikan potensi yang sebenarnya sehingga DISPENDA Kota Batam akan terpacu untuk mencapai target tersebut dan dapat meningkatkan penerimaan pajak reklame.

2. Perlu melakukan sosialisasi secara rutin terhadap wajib pajak guna meningkatkan kesadaran wajib pajak terhadap kewajibannya dalam hal ketaatan pembayaran pajak tepat waktu dan tepat jumlah. DISPENDA juga diharap mampu memberikan sanksi tegas terhadap wajib pajak yang kurang taat dalam melaksanakan kewajibannya.

3. Diharapkan pada penelitian berikutnya yang akan membahas topik yang sama, agar memperluas ruang lingkup penelitiannya.

\section{UCAPAN TERIMAKASIH}

Peneliti mengucapkan terima kasih kepada pihak-pihak yang telah memberikan dukungan dan dorongan dalam melakukan penelitian ini. Penghargaan dan ucapan terima kasih kepada Kemenristekdikti yang telah mendanai penelitian ini.

\section{DAFTAR PUSTAKA}

Aquinus, Thomas. (2018). Dari 75 Ribuan UMKM, Hanya 2.105 UMKM Memanfaatkan Dana Bergulir dari Pemko Batam. TrubusPreneur. https://preneur.trubus.id/post/dari-75ribuan-umkm-hanya-2-105-umkm-memanfaatkan-dana-bergulir-dari-pemko-batam-8392

Achim, A.M, dan Chis, A.O. (2014). Financial Accounting Quality and Its Defining Characteristics. SEA-Practical Application of Science. 3(5): 93-98. http://www.academia.edu/25552550/FINANCIAL_ACCOUNTING_QUALITY_AND_I T S_DEFINING_CHARACTERISTICS

Hastuti, Indra. (2012). Sistem Informasi Akuntansi Sebagai Alat Komunikasi Perusahaan Dengan Pihak Pemakai. Jurnal Ilmiah Teknologi Informasi dan Komunikasi. Duta.com ISSN: 2086-9436. 3(1). http://journal.stmikdb.ac.id/index.php/dutacom/article/view/66

Humairoh, Iftitah Dian. (2013). Pengaruh Kompetensi Sumber Daya Manusia (SDM) Terhadap Kualitas Laporan Keuangan Pemerintah Daerah (Studi Empiris Pada SKPD Kabupaten Jember), Skripsi Universitas Jember. http://repository.unej.ac.id/handle/123456789/63134

Krismiaji. (2010). Sistem Informasi Akuntansi. Yogyakarta. UPP AMP YKPN

Mulyadi. (2016). Sistem Akuntansi. Jakarta. Salemba Empat.

Peraturan Pemerintah Nomor 71 Republik Indonesia. (2010). Standar Akuntansi Pemerintahan. Jakarta.

Pemerintah Kota Surakarta. (2010). Perda Kota Surakarta No 7 tahun 2010 tentang Pokokpokok Pengelolaan Keuangan Daerah. Surakarta: Pemkot Surakarta.

Roviyantie, Devi. (2011). Pengaruh Kompetensi Sumber daya Manusia dan Penerapan Sistem Akuntansi Keuangan Daerah terhadap Kualitas Laporan Keuangan Pemerintah Daerah (Survei Pada Organisasi Perangkat Daerah Kabupaten Tasikmalaya. Universitas Siliwangi.

Ramadhani, suci. (2017). Kadin Batam Deklasikan Kebangkitan UMKM di Kota Batam. Batam Today.com. $\quad$ http://m.batamtoday.com/berita95923-Kadin-Batam-DeklasikanKebangkitan-UMKM-di-Kota-Batam.html

Rachmawan, Budiarto, dkk. (2015). Pengembangan UMKM antara Konseptual dan Pengalaman Praktis, Yogyakarta: Gadjah Mada. University Press. 
Sutabri, Tata. (2014). Pengantar Teknologi Informasi. Edisi Pertama. Penerbit Andi. Yogyakarta.

Undang-Undang No. $\quad 8 . \quad$ (1999). Perlindungan Konsumen. www.hukumonline.com/pusatdata/downloadfile/.../parent/447 